\title{
Isolation, identification and molecular characterization of contagious ecthyma virus from goat and sheep
}

Jahangir Alam, ${ }^{1}$ Md. Shahin Alam, ${ }^{1}$ Md. Giasuddin, ${ }^{1}$ Papia Monoura, ${ }^{1}$ Md. Abdus Samad, ${ }^{1}$ Md. Hasan-Al-Faruque, ${ }^{1}$ Md. Bahanur Rahman,${ }^{2}$ Md. Shahidur Rahman Khan, ${ }^{2}$ Md. Ershaduzzaman, ${ }^{1}$ MJFA Taimur ${ }^{1}$

${ }^{1}$ Bangladesh Livestock Research Institute and ${ }^{2}$ Bangladesh Agricultural University, Mymensingh

\begin{abstract}
Contagious ecthyma (CE) is one of the most widespread viral diseases; primarily affect goat and sheep but also reported from human, reindeer, musk ox, dog, cat, red squirrel etc. The disease is caused by contagious ecthyma virus (CEV) and he virus is circulating in Bangladesh. Present study was aimed at isolation, identification and molecular characterization of the CEV circulating in Bangladesh. A total of 13 samples (scab materials; 11 from goat and 2 from sheep) were collected from three different farms of Sylhet and Dhaka divisions followed by processing for virus detection by PCR and isolation in Vero cell. Four different sets of primers were used targeting four different genes of CEV. Of these samples, 10 ( 8 from goat and 2 from sheep) were found positive by PCR. From these positive samples three viruses were isolated. Sequencing of different genes of several CEV isolates has been done directly from PCR product using automated DNA sequencer 3010 Genetic Analyzer available at the National Reference Laboratory for Avian Influenza (NRL-AI), Bangladesh. Bangladeshi isolates were found to have $95-99 \%$ identity to each other. When compared to viruses from other countries, high homology (92-96\%) was observed to viruses from New Zealand and India, and phylogenetically clustered with them. This is the first report of molecular characterization, though partial, of CEV in Bangladesh.
\end{abstract}

(Keywords: Contagious ecthyma virus, detection, PCR, molecular characterization)

\section{Introduction}

Contagious ecthyma (CE), also known as orf, contagious pastular dermatitis, sore mouth, or scabby mouth, is perhaps the most commonly encountered skin disease in domestic goats and sheep (Beck and Taylor, 1974). The disease has also been reported from human, reindeer, musk ox, dog, cat, red squirrel etc (Carr, 1968; Blood, 1971). This disease is seen in virtually every place in the world. All breed and age groups of goat and sheep are susceptible to this disease, although young animals are more commonly affected. The disease is caused by the DNA containing contagious ecthyma virus (CEV) under the genus Parapoxvirus of the family Poxviridae. The virus is very herd and live virus has been found in dried scabs up to 12 years after they were shed (Peacock,A..http://www.goatworld.com/articles/soremouth/soremouth.shtml). 
CE is an extremely infectious disease. Mazur and Machado (1989) reported that Orf is often not regarded as an important disease for adult animals, due to its low mortality. However, it is still a serious threat to newborn lambs where the mortality may reach can be as high as $93 \%$ in severe cases that are complicated by secondary infection. Mortality rate up to $10 \%$ has been reported in kids (Gumbrell and McGregor, 1997). Most animals will have mild loss of condition because of unwillingness to eat from the painful condition of their mouths. Young kids and lambs are more at risk to serious consequences because being abandoned by mothers when these become lame from foot lesions or refuse to drink because of their sore mouths. $\mathrm{CE}$ is most commonly seen on the lips and mouth of infected animals, but lesions may also occur on the udder and between the toes. The disease starts with water filled blebs that eventually become pustules. When the pustules break, raised brown scabs form over the resulting wounds. Animals that contact the disease usually develop a strong immunity and will not be reinfected for at least one year.

The disease not only has an economic impact on farmers but also has a considerable negative effect on animal welfare. Infected animals become sick, fail to thrive and are more susceptible to adventitious bacterial infections. The disease has been reported from many countries of the world. The symptomatic diagnosis of $\mathrm{CE}$ in Bangladesh was performed by Ershaduzzaman et al., in 2010 (Annual Research Review Workshop, 2010) and collected some samples from Khulna, Sylhet and Dhaka. The present study was undertaken to isolate, identify CEV from suspected field samples of goat and sheep and to characterize the viruses.

\section{Materials and methods}

\section{Cells}

African green monkey kidney cells (Vero cells) were cultured in $25 \mathrm{~cm}^{2}$ tissue culture flask containing Dulbeco`s Modified Eagle Medium (DMEM, Nissui Pharmaceutical Co. Ltd., Tokyo, Japan), supplemented with penicillin (Gibco, Life Technologies) 100 units $\mathrm{ml}^{-1}$, streptomycin $100 \mu \mathrm{g} \mathrm{m} l^{-1}$, amphotericin B $0.5 \mu \mathrm{g} \mathrm{ml}^{-1}$, 4mM L-glutamine, and heat-inactivated $10 \%(\mathrm{~V} / \mathrm{V})$ fetal calf serum (FCS), and were incubated at humidified environment at $37^{\circ} \mathrm{C}$ in incubator. When necessary, cells were maintained in serum free medium. 


\section{Sample collection and inocula preparation}

A total of 13 scab materials were collected from contagious ecthyma suspected goat $(n=11)$ and sheep $(n=2)$ of three different farms of Dhaka and Sylhet divisions with the history of papular lesions in oral commissure, muzzle and lower jaw regions (Table 1). Samples were minced using sterile scissors and forceps and then triturated in a sterile pestle and mortar with phosphate buffered saline to make 10 percent suspension. The mixture was clarified at $15000 \times \mathrm{g}$ for 3 minutes and then a portion of supernatant was transferred to a microcentrifuge tube for DNA extraction. Antibiotic such as penicillin 10,000units $\mathrm{ml}^{-1}$, streptomycin $10,000 \mu \mathrm{g} \mathrm{ml} \mathrm{m}^{-1}$, gentamycin $5000 \mu \mathrm{g} \mathrm{ml} \mathrm{m}^{-1}$, and amphotericin B 50 $\mu \mathrm{g} \mathrm{ml}^{-1}$ (Jahangir et al., 2008) was added to the rest of the supernatant and stored at $-80^{\circ} \mathrm{C}$ to use for virus isolation.

Table 1. Distribution of samples collected from different farms

\begin{tabular}{lllll}
\hline Farm & Species & No of sample & No positive & \% positive \\
\hline A & Sheep & 2 & 2 & 100 \\
B & Goat & 3 & 0 & 0 \\
C & Goat & 8 & 8 & 100 \\
Total & & 13 & & \\
\hline
\end{tabular}

\section{DNA Extraction}

DNA was extracted from sample using Wizard Genomic DNA Purification Kit (Promega, USA) according to manufacturer's instruction. Briefly, about 300 $\mu 1$ of inoculum was mixed with $700 \mu 1$ celllysis solution and mixed well by pipetting. Then $3 \mu \mathrm{l}$ RNase solution was added, mixed well and incubates at $38^{\circ} \mathrm{C}$ for 20 minutes. Up on incubation $200 \mu \mathrm{l}$ of protein precipitation solution was added, vortex and chilled in $4^{\circ} \mathrm{C}$ for 5 minutes followed by centrifugation at 16,000 $\times \mathrm{g}$ for 4 minutes. About $600 \mu 1$ of supernatant was added with equal volume of isopropanol and mixed gently by inversion followed by centrifugation at $16,000 \times \mathrm{g}$ for 1 minute. Then supernatant was removed and $600 \mu \mathrm{l} 70 \%$ ethanol was added, mixed well and centrifugation at $16,000 \times \mathrm{g}$ for 1 minute. Then, supernatant was discarded and air dried of pellet for 15 minutes. Finally 
$30 \mu 1$ of DNA rehydration solution was added and incubate at $65^{\circ} \mathrm{C}$ for 1 hour in water bath, and then the DNA was stored at $-20^{\circ} \mathrm{C}$ until use.

\section{Primer}

A total of four sets of primers targeting four different genes of CEV were used to detect the CEV in the test sample. The primers were synthesized by Bio Basic Inc, Canada and supplied by Mars syndicate (Bangladesh). Sequences of primers along with the reference are shown in Table 2.

Table 2. Sequences and source of primers used in the study

\begin{tabular}{lll}
\hline Sl. No. & Sequence $\left(\mathbf{5}^{\prime}-\mathbf{3}^{\prime}\right)$ & \multicolumn{2}{l}{ Source } \\
\hline 1. & GIF5 : GCT CTA GGA AAG ATG GCG TG & $\begin{array}{l}\text { Klein, and } \\
\text { Tryland, 2005. }\end{array}$ \\
& GIF6: GTA CTC CTG GCT GAA GAG CG & Klein, and \\
2. & vIL-10-3: ATG CTA CTC ACA CAG TCG CTC C & Tryland, 2005 \\
& vIL-10-4: TAT GTC GAA CTC GCT CAT GGC C & Chan et al., \\
3. & OVA32LF1: GAG GGC GCG AGC ACC ATT TA & 2009 \\
& OVA32LR1: CGG AGC CGG TAA TTT AGT GAC AGT & Guo et al., \\
4. & VIR1: TTA GAA GCT GAT GCC GCA G & 2004 \\
\hline
\end{tabular}

\section{Polymerase chain reaction $(\mathrm{PCR})$}

PCR was performed using PCR Reagent System (Invitrogen, USA). The PCR reaction mixture consisted of 10X PCR Buffer with $15 \mathrm{mM} \mathrm{MgCl} 2.5 \mu 1,10 \mathrm{mM}$ dNTP mix $0.5 \mu$, Taq DNA polymerase $(5 \mathrm{U} / \mu \mathrm{l}) 0.5 \mu \mathrm{l}, 100$ pmole forward and reverse primer $0.5 \mu 1$ each, DNA template $5 \mu 1$ and nuclease free water $15.5 \mu l$. Thermal cycling conditions were initial denaturation at $94^{\circ} \mathrm{C}$ for 5 minutes followed by 35 cycles of denaturation at $94^{\circ} \mathrm{C}$ for 30 seconds, annealing at $57^{\circ} \mathrm{C}$ for 1 minute and extension at $72^{\circ} \mathrm{C}$ for 1 minute. Final extension was at $72^{\circ} \mathrm{C}$ for 10 minutes. This condition was for primers GIF5 and GIF6. For other primers specified conditions were used (Klein, and Tryland, 2005, Chan et al., 2009 and Guo et al., 2004). Amplicons were analyzed by gel electrophoresis in a $1.0 \%$ agarose gel using TAE buffer with ethidium bromide for DNA staining. 


\section{Virus isolation and identification}

Virus isolation from inoculumn prepared from scab materials was performed in Vero cell. Briefly, $25 \mathrm{~cm}^{2}$ tissue culture flask (Greiner, Germany) was seeded with $6 \mathrm{ml}$ of growth medium containing $\sim 1 \times 10^{5}$ cells $/ \mathrm{ml}$. To remove floating dead cells, at $100 \%$ confluent monolayer, cells were washed thrice with PBS ( $\mathrm{pH} 7.2$ ). Then the cells were infected with $200 \mu \mathrm{l}$ of inoculum and incubated at $37^{\circ} \mathrm{C}$ for $1 \mathrm{hr}$. To facilitate adsorption the flask was tilt every 15 minutes. Upon incubation, $6 \mathrm{ml}$ of serum free medium was added and incubated at $37^{\circ} \mathrm{C}$ for 8 days. The cells were observed twice daily and cytopathic effect (CPE) was recorded up to 8 days post inoculation (dpi). Negative control was run along with test sample. PCR was employed to identify the virus from culture supernatant.

\section{Sequencing}

PRC product was purified using EZ-10 Spin Column PCR Products Purification KitsBS363 (Bio Basic Inc, Canada) according to manufacturer's instruction and stored at $20^{\circ} \mathrm{C}$. Purified PCR product was sequenced by dideoxy terminating method using Dye Terminator Cycle Sequencing FS Ready Reaction Kit (Applied Biosystems, USA). The nucleotide sequencing reaction mixture contained $0.5 \mu \mathrm{l}$ purified PCR product, $2 \mu \mathrm{l}$ of primer ( $4 \mathrm{pmol} / \mu \mathrm{l}), 4 \mu \mathrm{l}$ of BigDye Terminator v3.1 (Cycle Sequencing Kit; ABI, Foster City, CA), and $4 \mu 1$ of BigDye ${ }^{\circledR}$ Terminator v1.1, v3.1 5X sequencing buffer (Applied Biosystems), and double distilled water amount necessary to make final volume of $20 \mu 1$, according to the manufacturer's instructions. The sequence reaction was performed as follows: denaturation for $1 \mathrm{~min}$ at $94^{\circ} \mathrm{C}$, followed by 25 cycles of PCR amplification, with each cycle consisting of $45 \mathrm{sec}$ of denaturation at $96^{\circ} \mathrm{C}, 30 \mathrm{sec}$ of annealing at $50^{\circ} \mathrm{C}$, and $4 \mathrm{~min}$ of elongation at $60^{\circ} \mathrm{C}$. Then the product was purified by BigDye ${ }^{\circledR}$ XTerminator purification kit (Applied Biosystems, USA). The primer used for PCR was used in sequencing reaction. Sequencing was done from both forward and reverse direction. Nucleotide sequences were determined using an automated DNA sequencer 3110 Genetic Analyzer (Applied Biosystems, USA) available at National Reference Laboratory for Avian Influenza (NRL-AI), edited with SeqEscape V2.6 software. 


\section{Phylogenetic analysis}

Multiple sequence alignments and processing were performed with the Molecular Evolutionary Genetics Analysis (MEGA) version 4.1.0 software (Tamura et al., 2007) with an engine based on the ClustalW algorithm. Blast searches were used to retrieve the homologous sequences from the GenBank database. The phylogenetic analyses were performed using neighbor joining tree inference analysis with the 1000 bootstrap replications to assign confidence levels to branches.

\section{Results and Discussion}

$\mathrm{CE}$ is a viral disease mostly affects small ruminants. Different degrees of proliferative lesions were found in different parts of the body of affected animals. Figure 1 shows the proliferative lesions of ecthyma in a young goat. No differences were found the occurrences of diseases in male and female animal. However, young animals were found to be mostly affected by this virus. The virus can affect different

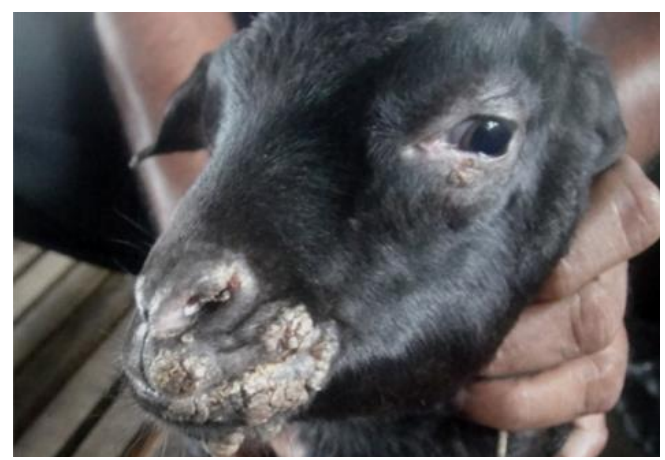

Fig. 1. Contagious ecthyma affected goat. Scab is formed around the mouth parts of the body and the degree of lesions differs among different animals. During sample collection no mortality was recorded. In goats and sheep, contagious ecthyma is clinically recognized by the appearance of macules and papules that progress to vesicles, pustules, and proliferative lesions mainly at the mucocutaneous junctions of the mouth and nose but can extend to the udder and teats, coronary band, and anus (Gelberg, 2007 and Navarre et al. 2002). It has been reported that mortality from this disease may reach 10 and $93 \%$ in kids and newborn lambs, respectively that are complicated by secondary infection. Lessions usually crust over, rapidly become growing scabs, and heal spontaneously within 4 weeks (McKeever et al. 1988). Scabs contain large numbers of the virus and protect the virus from environmental inactivation for up to months and years; scabs are a source of further infections and contribute to the contamination of pastures and sheds (Anderson et al., 2002, Haig et al. 2002).

\section{Detection of CEV by PCR}

Scab samples $(n=13)$ have been collected from three different farms of Sylhet and Dhaka divisions of Bangladesh. Out of 13 samples 10 were found positive for CEV by 
PCR using 4 different sets of primers. Out of 10 positive samples, 8 were obtained from goat and 2 from sheep. The age of CEV positive animals ranged from 3 to 8 months. Infection was also found in adult animals. Figure 2 shows the amplification of about 400 base pair DNA from tensamples. Viruses in the panel 1-8 were derived from goat and 9-10 from sheep. GIF5 and GIF6 primer set was used1 $2 \begin{array}{lllllllll}2 & 4 & 5 & \text { M } & 6 & 7 & 8 & 9 & 10\end{array}$ to amplify this DNA. This primer set targets the Granulocyte-macrophage-colony-stimulating factor (GM-CSF) and Interleukin-2 inhibition factor (GIF). Other three sets of primers also amplify specific base pair DNA from CEV genome (data not

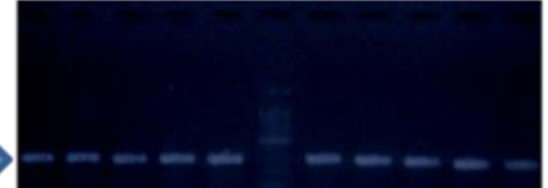

Fig. 2. Ecthyma positive samples by PCR. Lane M: Marker, Lane 110: Test sample shown). The VIR1 and VIR2 primer target the viral interferon resistance gene, while the OVA32LF1 and OVA32LR1 targets A32L gene which encodes ATPAse of CEV. Viral interlukin-10 gene was amplified by vIL10-3 and vIL10-4 primer sets. Primer pairs used in this study resulted in amplification of DNA fragments of specific sizes and have been shown to be effective in amplifying CE viral DNA (Guo et al., 2004; Klein, and Tryland, 2005; Chan et al., 2009).

\section{Virus isolation in vero cell}

For virus isolation monolayer of Vero cells in $25 \mathrm{~cm}^{2}$ flask was inoculated with samples found CEV positive by PCR. Cells were observed for CPE daily for 8 consecutive days. $\mathrm{CPE}$, characterized by cell rounding, detachment of cells, etc., were observed in Vero cells (Fig. 3). CPE induced by sample number 4 obtained from goat just 2 dpi which reached about $90 \%$ at 5 dpi (Fig. 3). On the other hand, sample number 5
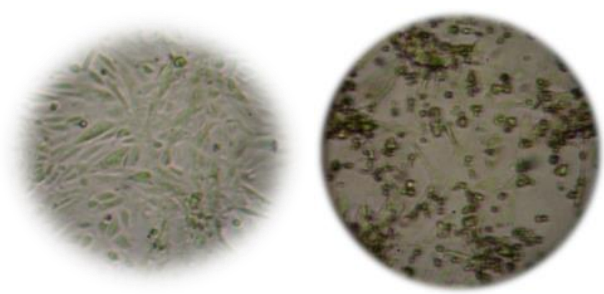

Fig. 3. Vero cell normal (left) and cytopathc effect induced by CEV (right). and 10 obtained from goat and sheep, respectively induced slight changes in cell at 8 dpi. By 8 dpi negative control cells were also detached from the bottom of the flask. Viral existence in the culture fluid was confirmed in three samples by PCR (Table 3). Guo et al. (2003) observed rounding, pyknosis and detachment of Madin darby Ovine Kidney (MDOK) cells infected with scab or vaccine suspensions. But they did not observe such changes in mock-infected cells. They also reported that in MDOK cells CPE was evident only after 3 days of the third blind 
passage. It is very difficult to explain why the viruses in PCR positive other samples did not grow in Vero cell in the present study. It may be assumed that in the sample the viruses were non-infective or during collection and processing of sample the viruses become inactivated. Besides, other factors like inhibition of viral adherence to specific receptors in Vero cell or any other unknown growth inhibitory factors may contribute in non-isolation of virus from PCR positive field samples. It is reported that infectivity of CEV vary according to speciesof animal (Guo et al. 2003). Occasionally, ecthyma virus is presumed to cause severe proliferative dermatitis in goats. However, virus isolation and characterization is seldom achieved (Abu and Housawi, 1997).

Table 3. Isolation and identification of CEV from field samples

\begin{tabular}{|c|c|c|c|c|c|c|c|c|c|}
\hline \multirow{2}{*}{$\begin{array}{l}\text { Sample } \\
\text { ID }\end{array}$} & \multicolumn{8}{|c|}{ CPE days post inoculation (dpi) } & \multirow[t]{2}{*}{ PCR } \\
\hline & 1 & 2 & 3 & 4 & 5 & 6 & 7 & 8 & \\
\hline 1 & - & - & - & - & - & - & - & - & \\
\hline 2 & - & - & - & - & - & - & - & - & \\
\hline 3 & - & - & - & - & - & - & - & - & \\
\hline 4 & - & + & $<++$ & $>+++$ & ++++ & & & & CEV \\
\hline 5 & - & - & - & - & - & - & - & ++ & CEV \\
\hline 6 & - & - & - & - & - & - & - & - & \\
\hline 7 & - & - & - & - & - & - & - & - & \\
\hline 8 & - & - & - & - & - & - & - & - & \\
\hline 9 & - & - & - & - & - & - & - & - & \\
\hline 10 & - & - & & & & - & - & ++ & CEV \\
\hline
\end{tabular}

\section{Gene sequencing and phylogenetic analysis}

Sequencing was performed at NRL-AI using BigDye Terminator Cycle sequencing kit and read in 3110 automated DNA Sequencer (. Genetic analysis revealed that the genes of Bangladeshi viruses have 95-99\% identity to each other. When compared to viruses from other countries, high homology (92-96\%) was observed to viruses derived from New Zealand and India. Phylogenic analysis was performed by analyzing the nucleotide sequences of Bangladeshi isolates with those of CEV obtained from the GenBank database by neighbor-joining trees using MEGA4: molecular evolutionary genetics analysis (MEGA) software version 4.0. Phylogenetically Bangladeshi viruses were clustered with viruses from New Zealand and India (Fig. 4). 

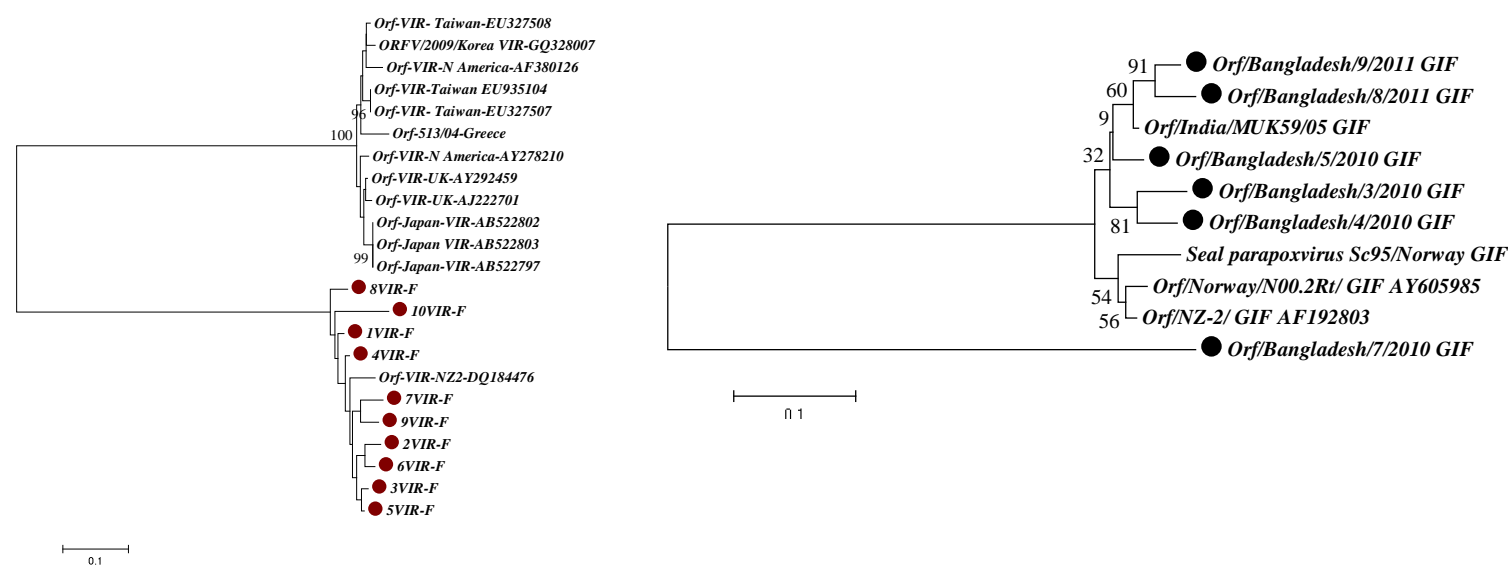

Fig. 4. Phylogenetic analysis of CEV isolated from Goat and Sheep in Bangladesh. An unrooted neighbor joining tree of nucleotide sequences of viral interferon resistant gene (left) and granulocyte-macrophage colony stimulating factor and interleukin 2 inhibition factor (GIF) genes (right) were generated, followed by 1000 replications of bootstrap re-sampling. Bangladeshi isolates were marked by circle.

\section{Conclusion}

CEV viruses were found to circulating in Bangladesh. Young goats and sheep were found more susceptible to infection. Of the 13 samples, 10 were found positive for CEV by PCR. Based on partial nucleotide sequence data generated through this study, viruses were found to be closely related to each other. Most closely related viruses were found to be derived from India and New Zealand and phylogenetically Bangladeshi isolates were clustered with them.

\section{Reference}

Abu, E.E. and Housawi, F.M. 1997. Severe long-lasting contagious ecthyma infection in a goat's kid. Zentralbl. Veterinarmed. Reihe B 44, 561- 564.

Anderson D.E., Rings, D.M. and Pugh, D.G. 2002. Diseases of the integumentary. In:

Pugh DG, ed. Sheep and goat medicine. Philadelphia: Saunders, 2002;197-222.

Beck, C.C., and Taylor, W.B. 1974. Orf: Its aawrful. Vet. Med. Small Anim. Cli., 69: 1413-1417.

Blood, D.A. 1971. Contagious ecthyma in Rocky Mountain bighorn sheep. J. Wildl. Manage., 35: 270-275.

Carr, R.W. 1968. A case of orf (ecthyma contagium; . contagious pastular dermatitis) contracted by a human forma wild Alaskan mountain goat. Alaska Med., 10: 7577.

Chan, K.W., Hsu, W.L., Wang, C.Y., Yang, C.H., Lin, F.Y., Chulakasian, S. and Wong, 
M. L. 2009. Differential diagnosis of orf viruses by a single-step PCR. J. Virol. Methods, 160: 85-89.

Gelberg, H.B. 2007. Alimentary system. In: McGavin MD, Zachary JF, eds. Pathological basis of veterinary disease. 4th ed. St Louis: Mosby, 2007;301-391.

Gumbrell, R.C., McGregor, D.A., 1997. Outbreak of severe fatal orf in lambs. Vet. Rec., 141, 150_151.

Guo, J., Zhang, Z., Edwards, J.F., Ermel, R.W., Taylor, C.Jr. and de la ConchaBermejillo, A. 2003. Characterization of a North American orf virus isolated from a goat with persistent, proliferative dermatitis. Virus Res., 93: 169-179.

Guo, J., Rasmussen, J., Wünschmann, A. and de la Concha-Bermejillo, A., 2004. Genetic characterization of orf viruses isolated from various ruminant species of a zoo. Vet. Microbiol., 99: 81-92.

Haig, D.M., Thomson, J., McInnes, C., et al. 2002. Orf virus immuno-modulation and the host immune response. Vet Immunol Immunopathol., 87:395-399.

Jahangir, A., Watanabe, Y., Chinen, O., Yamazaki, S., Sakai, K., Okamura, M., Nakamura, M. and Takehara, K. 2008. Surveillance of avian influenza viruses in Northern pintails (Anas acuta) in Tohoku District, Japan. Avian Dis., 52: 49-53.

Klein, J. and Tryland, M. 2005. Characterization of parapox viruses isolated from Norwegiansemi-domesticated reindeer (Rangifer tarandus tarandus). Virology Journal, 2 (79): 1-10.

McKeever, D.J., Jenkinson, D.M., Hutchison. G., et al. 1988. Studies of the pathogenesis of orf virus infection in sheep. J Comp Pathol., 99:317-328.

Mazur, C. and Machado R.D. (1989). Detection of contagious pustular dermatitis virus of goats in a severe outbreak. Vet. Rec., 125: 419-420.

Navarre, C.B., Lowder, M.Q. and Pugh, D.G. 2002. Oral-esophageal diseases. In: Pugh DG, ed. Sheep and goat medicine. Philadelphia: Saunders, 2002;61-68.

Peacock, A. Sore mouth, Contagious ecthyma also known as CE. http://www.goatworld.com/articles/soremouth/soremouth.shtml. Accessed on March 27, 2013.

Tamura, K., Dudley, J., Nei, M. and Kumar, S. 2007. MEGA4: Molecular Evolutionary Genetics Analysis (MEGA) software version 4.0. Mol. Biol. Evol., 24: 15961599. 